\title{
Feeding habits of breastfed and non-breastfed children up to 1 year old
}

\author{
Graciete O. Vieira, ${ }^{1}$ Luciana R. Silva, ${ }^{2}$ Tatiana de 0 . Vieira, ${ }^{3}$ \\ João Aprígio G. Almeida, ${ }^{4}$ Vilma A. Cabral ${ }^{5}$
}

\begin{abstract}
Objective: To describe the eating habits of breastfed and non-breastfed children through the analysis of food intake by children younger than one year of age in Feira de Santana in 2001.

Methods: Cross-sectional study. The mothers of children younger than one year answered a questionnaire during the national vaccination day in $44(71 \%)$ vaccination units selected by simple stratification. 2,319 children were evaluated, representing $24.3 \%$ of the estimated population. Prevalence ratio and $95 \%$ confidence interval were calculated. Statistical significance was determined using the chi-square test.

Results: Non-breastfed children aged four months or younger were 8.2 and 6.7 times more likely to receive the family food ( $95 \%$ CI: $3.23-20.66$ ) or vegetable soup (95\% CI: 3.84-11.78), respectively. In the same age group, the prevalence of non-breastfed children receiving water, juice, and fruit was significantly higher in relation to breastfed children ( $70.7 \%$ vs $19.7 \%, 63.3 \%$ vs $26.7 \%, 33.3 \%$ vs $4.9 \%$ and $14.4 \%$ vs $1.4 \%$, respectively).

Conclusion: Breastfed children had healthier habits than non-breastfed children in terms of the introduction of complementary foods.
\end{abstract}

J Pediatr (Rio J). 2004;80(5):411-6: Breast feeding, feed, feeding behavior, mixed feeding.

\section{Introduction}

Human milk offers the nutrients that a child needs to begin a healthy life and represents the essential food for infants until their sixth month of life, as an exclusive food, and from then onwards should be complemented with other sources of nutrition until at least 2 years of age.1,2

1. Doctoral student, Universidade Federal da Bahia (UFBA). Assistant professor, Universidade Estadual de Feira de Santana (UEFS), Feira de Santana, BA, Brazil.

2. Full professor of Pediatrics and Chief of the Service of Pediatric Gastroenterology and Hepatology, Universidade Federal da Bahia (UFBA), Salvador, BA, Brazil.

3. Medical student, Escola Bahiana de Medicina e Saúde Pública (EBMSP), Salvador, BA, Brazil.

4. Ph.D., Instituto Fernandes Figueira/Fundação Oswaldo Cruz (IFF/ FIOCRUZ). Coordinator of the National Reference Center for Human Milk Banks.

5. M.Sc., Universidade Federal da Bahia (UFBA), Salvador, BA, Brazil.

Manuscript received Oct 28 2003, accepted for publication Jun 232004.

Suggested citation: Vieira GO, Silva LR, Vieira TO, Almeida JAG, Cabral VA. Feeding habits of breastfed and non-breastfed children up to 1 year old. J Pediatr (Rio J). 2004;80:411-6.
Earlier World Health Organization (WHO) documents recommended exclusive breastfeeding for 4-6 months. ${ }^{3}$ Based on scientific evidence of the benefits of exclusive breastfeeding, many countries, including Brazil, officially adopted the recommendation of complementary foods at 6 months of age. ${ }^{4,5}$ Nowadays the WHO and domestic policy concur on the recommendation of exclusive breastfeeding for the first 6 months of life. ${ }^{1,5}$

In search of a consensus on the optimum duration of exclusive breastfeeding, the WHO performed a systematic review of published research and concluded that none of them demonstrated weight or height gain deficits for children exclusively fed breastmilk during the first six months of their lives. ${ }^{1}$ The principal justification against the introduction of complementary foodstuffs before the sixth month of life was the increased risk of episodes of gastrointestinal infections. $1,4,6,7$

In addition to the increased infant morbidity and mortality, there are innumerable disadvantages to the precipitate introduction of complementary foods, of note among which are the interference in nutrient absorption, such as iron and 
zinc $^{4}$ the increased risk of food allergies ${ }^{6}$ and the increased incidence of chronic-degenerative diseases during adult life. 8

Furthermore, with the introduction of complementary foods before 6 months of age, the child will receive less human milk, with a consequent reduction in milk production on the part of the nurturing mother, ${ }^{4}$ a reduced overall breastfeeding duration, a reduction in the efficacy of lactation as a contraceptive ${ }^{1}$ and interference in the baby's feeding habits. ${ }^{8}$ Even among non-breastfed children, the habitual recommendation for the introduction of solid foods is after 4 months of life. ${ }^{9}$

Notwithstanding the nutrition of a population does not only depend upon their access to adequate nutrition, but, more than anything else, on the education and culture of that population. Nutritional education begins extremely early, during the first months of life when the foundations of feeding habits are constructed. 8,10

The feeding behavior of a child is determined by its interaction with food, by its anatomophysiological development and by emotional, psychological, socioeconomic and cultural factors. ${ }^{8}$ Even so, the most marked influence on the formation of feeding habits is brought to bear by the product of the child's interaction with its mother or the person most involved with its feeding. ${ }^{9,11}$ It is important to remember that infants ingest the foods that they are offered and in the form that they are prepared.

The family offers a wide field for the child's social learning. The domestic environment, the parents' lifestyle and interfamily relationships can have a great influence on feeding and food preferences, and affect the energetic equilibrium of nutrition, through the availability and composition of foods. Thus, the family may establish the learning of a socially acceptable habit or insert new habits, contributing to the formation of an adequate or inadequate behavioral pattern. ${ }^{11}$

The objective of the present study was to describe the feeding habits of breastfed and non-breastfed children, following the introduction of liquid and semi-solid/solid foods during the first year of life. The use of pacifiers was also investigated, with respect of the presence or absence of breastfeeding. By means of an understanding of the factors associated with feeding habits, educational and preventative measures can be proposed for the formation of healthy feeding behavior and for the promotion of the health of both children and adults.

\section{Methods}

This is a cross-sectional population-based study, approved by the Ethics and Research Committee at the Universidade Federal da Bahia. The study population was made up of children less than one complete year old on the 25th of August, 2001, the Brazilian national vaccination day. The children resided in the city of Feira de Santana, presented at the selected vaccination stations and were accompanied by their mothers, who responded to the questionnaire.
The design was for a simple random sample. Vaccination took place at 62 units (health centers and schools). In order to ensure vaccination coverage, the Feira de Santana Department of Health divided the city into four "commands". A simple random sample was selected from each stratum (command). Forty-four centers (71\%) were selected by drawing lots out of the total of 62. A sample was calculated to represent $20 \%(1,912)$ of the estimated population of children aged up to 11 months and 29 days $(9,563)$. The questionnaire was administered to 2,323 (24.3\%) mothers.

Data collection was performed by 104 previously trained university students. The data collection form was developed in clear and objective language with closed, mutually exclusive, possible responses, in the majority of cases: yes, no and don't know. The questionnaire was administered in the form of direct interview. In order to assess the foodstuffs that were given to the children, a 24-hour dietary recall was used.

The two main variables under study were breastfeeding (primary independent variable) and feeding habit (dependent variable). Feeding habits were analyzed according to the type of complementary foods introduced into the child's diet, and their age on introduction. External variables investigated as having a possible influence on the primary association were: age of the child in days, sex, birth weight and pacifier sucking habit. Maternal characteristics investigated were: age, birth order, education, employment outside of the home and family income.

Complementary foods are defined as any liquid, semiliquid or solid food offered to the breastfed child. ${ }^{4}$ The liquid foods investigated were water, teas and juices and semisolid foods were mashed fruit and vegetables. The family meal was defined as a solid food prepared for normal adult consumption. Mothers who claimed to give nothing but breastmilk to their children were defined as in exclusive breastfeeding.

For the data analysis association measurements (prevalence ratio), with $95 \%$ confidence intervals and statistical significance were calculated using the chisquare test with its respective $p$ value. The statistical program employed was the Statistical Package for Social Science (SPSS), version 10.0 .

\section{Results}

Two thousand, three hundred and twenty-three mothers were interviewed, with four questionnaires being discarded due to incomplete data. On the data collection day, $69.2 \%$ $(1,603)$ of those less than one year old were breastfeeding. The prevalence of exclusive breastfeeding among those with ages less than or equal to 4 and 6 months, was 48.3 and $38.5 \%$, respectively.

Maternal characteristics were as follows: $58.8 \%$ were in the $20-29$ age group, $46.2 \%$ were primiparous and $23.3 \%$ were employed outside of the family home. Of the 1,640 mothers who were able to provide their family income, $49.6 \%$ said that it was between one and two times the Brazilian minimum wage. In terms of education, $37.5 \%$ had 
continued beyond compulsory basic education. Fifty-two point eight percent of the 2,319 children studies were aged 6 months or less, $7.3 \%$ were born weighing less than 2,500 grams, and $49.9 \%$ were male.

During their first month of life, breastfed children were already drinking water $(7.3 \%)$, teas $(23.2 \%)$ and juices $(2.7 \%)$ (Figure 1), although the non-breastfed children's consumption was significantly greater, when compared with the breastfed subset, being, for water, teas and juices, respectively, $30 \%(p=0.01), 50 \%(p=0.05)$ and $30 \%$ $(p=0.000)$.

Consumption of semi-solid/solid foods by breastfed children during the first month of life was at $0.7 \%$ for mashed fruit and the family meal, and $2 \%$ for mashed vegetables. No significant increase was observed in the consumption of these foods during the first 3 months of life (Figure 2). The non-breastfed infants consumed significantly more fruit and vegetable mashes and family meals during the first month of life, respectively, $10 \%(p=0.01), 20 \%$ $(p=0.02)$ and $10 \%(p=0.01)$.

Non-breastfed children aged 4 months or less presented significantly higher prevalence of water, tea, juice and fruit mash consumption than did breastfed children (Table 1). For the same age range, non-breastfed infants presented significantly greater chances of consuming mashed vegetables and family meals prematurely (Table 1 ). When pacifier use was compared between these two groups, significant differences were also observed, with greater prevalence among the non-breastfed children (Table 1).

No statistically significant differences were observed when the introduction of the family meal into the diets of children aged four months or less was analyzed in terms of the maternal co-variables recorded: aged less than 20 ( $p=$ $0.61)$, incomplete basic elementary schooling $(p=0.19)$, employment away from home $(p=0.20)$, family income less than twice the national minimum wage $(p=0.29)$.

\section{Discussion}

In recent years scientific evidence has been accumulating giving foundation to the importance of exclusive breastfeeding during the first 6 months, and of sustaining breastfeeding until at least 2 years of age.1,2,5

While breastfeeding prevalence has been shown to be higher in the city of Feira de Santana than the rates published in a number of different national studies, ${ }^{7,12}$ and while breastfed children have better feeding habits when compared with non-breastfed children, elevated consumption of liquids, particularly teas, was also observed, right from the first month of life.

The steady consumption of teas, at all ages during the first year, and the elevated consumption when compared with water and juices during the first month, reinforce the conviction that, when mothers are offering tea to their children the primary objective is not infant nutrition, but medication, in keeping with cultural factors that encourage the use of teas as treatments.
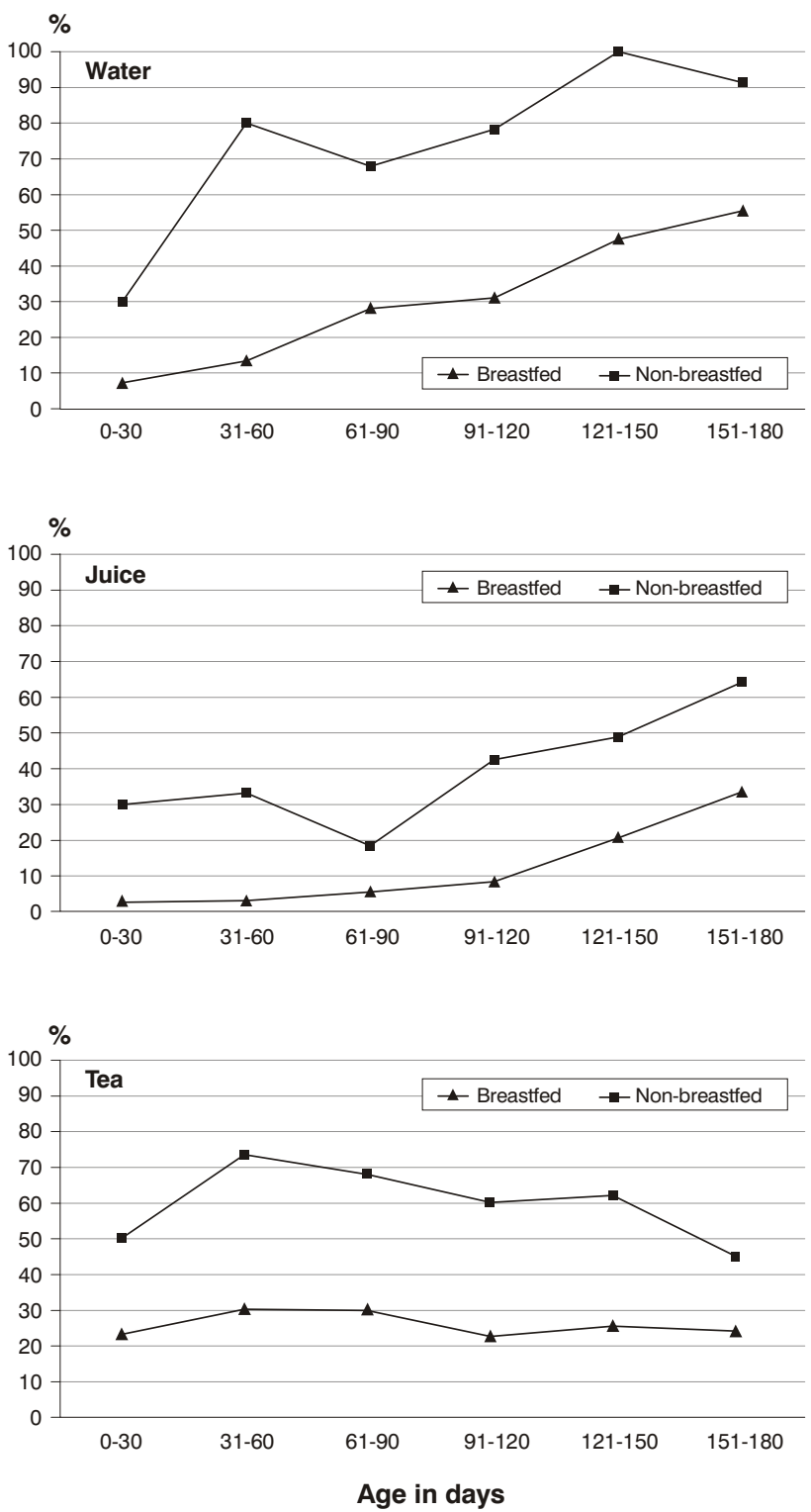

Figure 1 - Prevalence of children aged 6 months or less who drank water, juice and tea during the 24 hours before the survey

This, critical, situation has also been revealed in other studies which also found premature introduction of teas and water into babies' diets, ${ }^{13}$ explained by the mothers as for colic, gasses and thirst. ${ }^{14}$

The rural influence that can be observed in the city of Feira de Santana may help to explain the results, because it is known that rural communities have more traditional habits and that in them a large number of mothers begin breastfeeding and sustain it for longer, although they introduce complementary foods too early. ${ }^{15}$

Clearly the non-breastfed children ingest artificial milk, especially during the first months of life. One of the problems caused by the ingestion of protein to young babies is related 

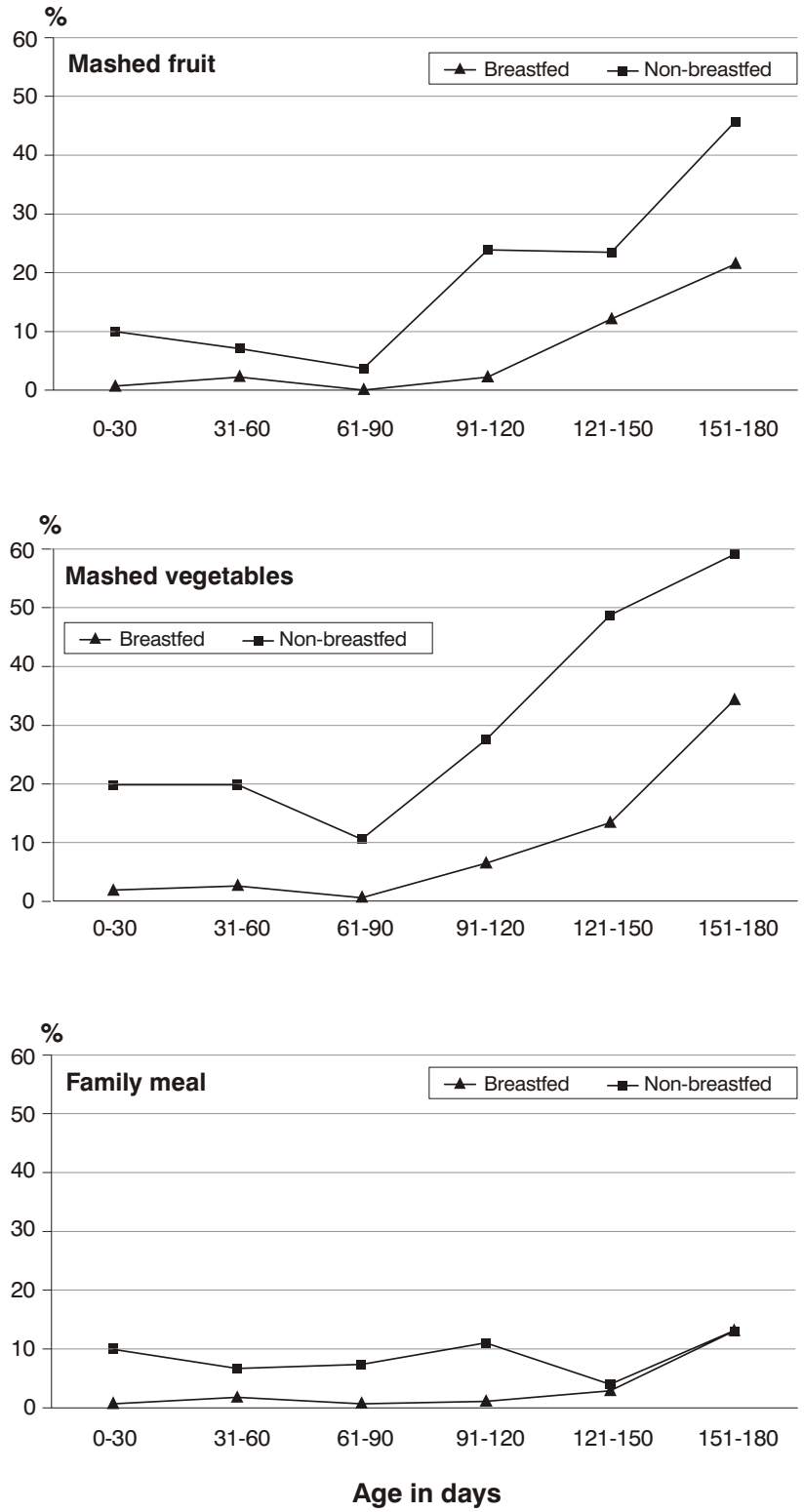

Figure 2 - Prevalence of children aged 6 months or less who ate mashed fruit and vegetables and family meal during the 24 hours before the survey

to the greater permeability of the intestinal mucosa during the neonatal period and during the first 3 months of life, whish results in the absorption of intact, undigested proteins and immunoresponse to the protein antigens present in milk-based formulae. ${ }^{6}$ This characteristic, in conjunction with immune mechanisms, explains the large number of children who develop cow's milk intolerance, not just because of the high antigenic power of the heterologous protein, but also because of how early it is given. ${ }^{6}$ Cow's milk is responsible for $20 \%$ of food allergies. ${ }^{4}$ For this reason, many countries' recommendations on the feeding of small children include delaying the introduction until 9-12 months
Table 1 - Consumption of water, juice, tea, mashed fruit and vegetables, family meals and use of pacifier according to the presence or absence of breastfeeding in children aged 4 months of less

\begin{tabular}{|c|c|c|c|c|c|}
\hline \multirow[t]{3}{*}{ Variable } & \multicolumn{4}{|c|}{ Breastfeeding } & \multirow{3}{*}{$\begin{array}{c}\text { PR } \\
(95 \% \mathrm{CI})\end{array}$} \\
\hline & \multicolumn{2}{|c|}{ Yes } & \multicolumn{2}{|c|}{ No } & \\
\hline & $\mathbf{n}$ & $\%$ & $\mathbf{n}$ & $\%$ & \\
\hline \multicolumn{6}{|l|}{ Water } \\
\hline Yes & 70 & 70.7 & 138 & 19.7 & 3.59 \\
\hline No & 29 & 29.3 & 562 & 80.3 & $(2.95-4.36)$ \\
\hline \multicolumn{6}{|l|}{ Juice } \\
\hline Yes & 33 & 33.3 & 34 & 4.9 & 6.82 \\
\hline No & 66 & 66.7 & 662 & 95.1 & $(4.44-10.49)$ \\
\hline \multicolumn{6}{|l|}{ Tea } \\
\hline Yes & 62 & 63.3 & 188 & 26.7 & 2.37 \\
\hline No & 36 & 36.7 & 516 & 73.3 & $(1.95-2.88)$ \\
\hline \multicolumn{6}{|c|}{ Mashed fruit } \\
\hline Yes & 14 & 14.4 & 10 & 1.4 & 10.18 \\
\hline No & 83 & 85.6 & 695 & 98.6 & $(4.65-22.27)$ \\
\hline \multicolumn{6}{|c|}{ Mashed vegetables } \\
\hline Yes & 21 & 21.0 & 22 & 3.1 & 6.73 \\
\hline No & 79 & 79.0 & 683 & 96.9 & $(3.84-11.78)$ \\
\hline \multicolumn{6}{|c|}{ Family meal } \\
\hline Yes & 9 & 9.3 & 8 & 1.1 & 8.17 \\
\hline No & 88 & 90.7 & 696 & 98.9 & $(3.23-20.66)$ \\
\hline \multicolumn{6}{|l|}{ Pacifier } \\
\hline Yes & 82 & 82.0 & 383 & 53.9 & 1.52 \\
\hline No & 18 & 18.0 & 328 & 46.1 & $(1.36-1.71)$ \\
\hline
\end{tabular}

PR $(95 \% \mathrm{Cl})=$ Prevalence ratio with confidence interval of $95 \%$.

of certain foods, including cow's milk as being highly antigenic, particularly when there is a family history of food allergy. 4

It has been demonstrated that the use of foods other than breastmilk in children's diets increases the risks of infant morbidity and mortality due to conditions associated with early weaning. ${ }^{1,16-19}$ A case-control study assessing the impact of breastfeeding on hospital admissions for pneumonia treatment, demonstrated that the rate of hospitalization for this condition was significantly higher among children who had received complementary feeding before 6 months, both for breastfed children and those fed artificially. ${ }^{18}$

In a cohort study Arifeen demonstrated that exclusive breastfeeding confers strong protection against death from diarrhea, and that predominant breastfeeding or the absence of breastfeeding were associated with a 2.2 times greater risk of dying from other infectious disease causes, and a 3.9 times greater risk of dying from respiratory infections and diarrhea. ${ }^{19}$

The current research showed that, during the first 3 months of life, the consumption of semi-solid/solid foods by breastfed children had low prevalence, increasing after the fourth month. It is possible that the end of maternity leave and the mother's return to work may contribute to the start 
of complementary feeding. It is also worth pointing out that the recommendation of exclusive breastfeeding for 4-6 months, still present in the majority of textbooks, based on the WHO's previous recommendations, ${ }^{3}$ may have led health professionals themselves to tell mothers to introduce complementary foods at this point, even in cases not defined as hypogalactous, or for children growing well.

Still on the subject of semi-solid/solid foods, it was found that children who are not breastfed consume them, inappropriately, right from the neonatal period, with statistically significant differences, when compared with those that are breastfed. Although the children studied were already consuming some complementary foods, exhibited better feeding habits than were found by the National Demographic and Health Census (Pesquisa Nacional sobre Demografia e Saúde), in which $52.9 \%$ of non-breastfed children and $6.2 \%$ of breastfed ones, were already eating oats or cereals. ${ }^{20}$

In addition to the fact that children are not physiologically prepared to digest solid foods before the sixth month of life, there is also a neurological immaturity swallow non-liquid foods, shown by the tongue protruding reflex with which they push away objects brought against their lips and, normally, reject foods offered by spoon. 3,9 Furthermore, chewing movements effectively begin at around 6 months, the point at which the introduction of more viscous foods is recommended. 3

Gastrointestinal disorders, in particular diarrhea, are common among infants who are given foods containing starch prematurely. ${ }^{3}$ The introduction of other foods, such as cereals and vegetables to the diet of breastfed children can prejudice the absorption of iron through a chelation mechanism, ${ }^{7}$ and excess undigested starch can interfere with the absorption of other foods and result in failure to thrive. ${ }^{3}$ Prepared food also involve greater risk of contamination resulting in infectious diarrhea.

Malnutrition can be related to inadequate weaning practices and the quality of foods consumed can be reflected, over both short and long term, in child health, by a nutritional programming that explains adult diseases related to inadequate nutritional practices during the neonatal period ${ }^{21}$ and childhood. ${ }^{22}$ Taking obesity as an example, breastfed children have a greater capacity for controlling serum cholesterol levels than do those receiving milk-based formula with implications for obesity prevention in adulthood. 22

In the studied population an association was found between the use of pacifiers and early weaning. A number of different studies have shown an inverse association between pacifier use and breastfeeding. ${ }^{23-25}$ One possible cause is the reduced frequency of daily suckling, which may lead to reduced breast stimulation and diminished milk production. ${ }^{26}$ Nevertheless, a causal relationship has not yet been well-established. One recent study suggested that pacifier use should be seen as an indication of breastfeeding problems because mothers use pacifiers when some difficulty with breastfeeding is encountered. 27
Maternal education and family income are always included as determinants in epidemiological studies. In this study however, no statistically significant differences were found when the introduction of the family meal to the diets of children four months old or less was evaluated according to these variables. This fact suggests that nutritional knowledge in Feira de Santana is related to references that pervade all social strata, showing the need for the development of studies that could widen our understanding of the cultural values of the municipality.

Finally, the analysis of liquid and semi-liquid elements as consumed by breastfed and non-breastfed children revealed that breastfeeding was associated with better feeding habits, proven by the lower prevalence of semisolid/solid food consumption before the 4th month of life.

It was also found that the consumption of juice and water by breastfed children interferes less than that of teas with exclusive breastfeeding indicators, showing the need for intervention measures through educational work with the population. It is known that to change culturallyestablished is difficult and that continuous work is necessary which respects the community's characteristics. For the process of change it is important to make health professionals and opinion-formers more aware and to stimulate educational programs to guide expectant mothers and mothers about their children's nutrition during the first year of life.

It is important to remember that the success of infant feeding practices depend upon supplying children with food of adequate quality that satisfies nutritional requirements, protects them from absorbing foreign substances and does not exceed the functional capacity of the gastrointestinal tract, in addition to being free of infectious agents, all of which qualities are to be found in human milk.

\section{References}

1. World Health Organization. The optimal duration of exclusive breastfeeding: a systematic review. Geneva: WHO; 2001.

2. World Health Organization. Report of the expert consultation on the optimal duration of exclusive breastfeeding. Geneva: WHO; 2001.

3. World Health Organization. Complementary feeding of young children in developing countries: a review of current scientific knowledge. Geneva: WHO; 1998.

4. Giugliani ERJ, Victora CG. Alimentação Complementar. J Pediatr (Rio J). 2000;76(Suppl 3):253-62.

5. Rea MF. O pediatra e a amamentação exclusiva. J Pediatr (Rio J). 2003;79:479-80

6. Vieira GO, Almeida JAG. Leite materno como fator de proteção contra doenças do tubo digestivo. In: Silva LR, organizadora. Urgências clínicas e cirúrgicas em gastroenterologia e hepatologia pediátricas. Rio de Janeiro: MEDSI; 2004. p. 951-9.

7. Vieira GO. Alimentação infantil e morbidade por diarréia na cidade de Feira de Santana, 2001 [dissertação]. Feira de Santana (BA): Universidade Estadual de Feira de Santana; 2002.

8. Ramos M, Stein LM. Desenvolvimento do comportamento alimentar infantil. J Pediatr (Rio J). 2000;76(Suppl 3):228-37.

9. Euclydes MP. Nutrição do lactente: base científica para uma alimentação adequada. $2^{a}$ ed. Minas Gerais: Suprema; 2000.

10. Giugliani ERJ, Lopez FA. Uma atualização em nutrição infantil. J Pediatr (Rio J). 2000;76(Suppl 3):227-8. 
11. Golan M. Influencia dos fatores ambientais domésticos no desenvolvimento e tratamento da obesidade infantil. Anais Nestlé 2002;62:31-42.

12. Ministério da Saúde. Prevalência do aleitamento materno nas capitais brasileiras e no Distrito Federal. Brasília: Ministério da Saúde/Secretária de Políticas de Saúde/Area de Saúde da Criança; 2001.

13. Montrone CVG, Arantes IS. Prevalência do aleitamento materno na cidade de São Carlos, São Paulo. J Pediatr (Rio J). 2000;76:138-42.

14. Moura EFA. Duração do período de aleitamento materno de crianças atendidas em ambulatório de pediatria. J Pediatr (Rio J). $1997 ; 73: 106-10$.

15. Caldeira AP, Goulart EMA. A situação do aleitamento em Montes Claros, Minas Gerais: estudo de uma amostra representativa. J Pediatr (Rio J). 2000;76:65-71.

16. Lamounier JA. Tendências do aleitamento materno no Brasil. Rev Med Minas Gerais. 1999;9:59-65.

17. World Health Organization. Collaborative Study Team on the role of breastfeeding on the prevention of infant mortality. Effect of breastfeeding on infant and child mortality due to infectious diseases in less developed countries: a pooled analysis. Lancet. 2000;355:451-5.

18. Cesar JA, Victora CG, Barros FC, Santos IS, Flores JA. Impact of breastfeeding on admission for pneumonia during postneonatal period in Brazil: nested case-control study. BMJ. 1999;318: 1316-20.

19. Arifeen S, Black RE, Antelman G, Baqui A, Caulfield L, Becker S. Exclusive breastfeeding reduces acute respiratory infection and diarrhea deaths among infants in Dhaka Slums. Pediatrics. 2001;108:167-71

20. Ministério da Saúde. Pesquisa Nacional de Demografia e Saúde 1996 - PNDS/96. Brasília: Sociedade Civil do Bem-estar Familiar no Brasil - BEMFAM; 1997.

21. Anderson JW, Johnstone BM, Remly DT. Breast-feeding and cognitive development: a meta-analysis. Am J Clin Nutr. 1999; 70:525-35
22. Oliveira FLC, Escrivão MAMS. Prevenção na infância e adolescência das doenças do adulto. In: Temas de nutrição em pediatria. Rio de Janeiro: Departamento de Nutrição/Sociedade Brasileira de Pediatria; 2001.

23. Soares MEM, Giugliani ERJ, Braun ML, Salgado ACN, Oliveira AP, Aguiar PR. Uso de chupetas e sua relação com o desmame precoce em população de crianças nascidas em Hospital Amigo da Criança. J Pediatr (Rio J). 2003;79:309-16.

24. Gorbe E, Kohalmi B, Gaal G, Szantho A, Rigo J, Harmath A, Csabay $L$, et al. The relationship between pacifier use, bottle feeding and breast feeding. J Matern Fetal Neonatal Méd. 2002;12:127-31.

25. Howard CR, Howard FM, Lanphear B, Eberly S, DeBlieck EA, Oakes $D$, et al. Randomized clinical trial of pacifier use and bottle-feeding or cupfeeding and their effect on breastfeeding. Pediatrics. 2003;11:511-8.

26. Lamounier JA. O efeito de bicos e chupetas no aleitamento materno. J Pediatr (Rio J). 2003;79:284-6.

27. Coutinho SB. Aleitamento materno exclusivo: um estudo de intervenção randomizado na zona da mata meridional de Pernambuco [tese]. Recife (PE): Universidade Federal de Pernambuco; 2003.

\author{
Corresponding author: \\ Graciete Oliveira Vieira \\ Rua Barão Rio Branco, 1499 - Centro \\ CEP 44025-000 - Feira de Santana, BA \\ Brazil \\ Phone: +55 (75) $221.3884 / 625.4156$ \\ Fax: +55 (75) 223.2351 \\ E-mail: graciete.vieira@terra.com.br
}

